\title{
Skeletal Anatomy of the Pectoral Girdle, Stylopodium and Zeugopodium of Caiman latirostris (Daudin, 1802) (Crocodylia: Alligatoridae)
}

\author{
Mariluce Ferreira Romão ${ }^{1}$, André Luiz Quagliatto $\operatorname{Santos}^{1} \&$ Fabiano Campos Lima ${ }^{2}$ \\ ${ }^{1}$ Federal University of Uberlândia (UFU), Rua Piauí, Bloco 4s, Bairro Jardim Umuarama, MG, Brazil \\ ${ }^{2}$ Laboratory of Comparative and Human Anatomy, Federal University of Goias (UFG), Jatoba Unit, Highway, \\ Goiânia, GO, Brazil \\ Correspondence: Mariluce Ferreira Romão, Faculty of Veterinary Medicine, Federal University of Uberlândia \\ (UFU), Rua Piauí, Bloco 4s, Bairro Jardim Umuarama, Uberlândia 38400-902, MG, Brazil. E-mail: \\ mariluce.ferreira@terra.com.br
}

Received: October 20, $2011 \quad$ Accepted: November 3, $2011 \quad$ Online Published: August 22, 2012

doi:10.5539/ijb.v4n4p40

URL: http://dx.doi.org/10.5539/ijb.v4n4p40

\begin{abstract}
The development of the skeleton can be better understood through new discoveries, using as reference tissue that is in a dynamic process of formation and resorption. This study used a young adult male specimen of $C$. latirostris, $1.50 \mathrm{~m}$ in length, belonging to the collection of the Wild Animal Research Laboratory of the Federal University of Uberlândia, fixed in 10\% formol. The specimen's skin, viscera and pectoral girdle, stylopodium and zeugopodium bone muscles were removed, and the bones were identified, recorded in photographs taken with a digital camera, and described. The findings demonstrate that the characteristics of the skeletal anatomy of the pectoral girdle, stylopodium and zeugopodium of $C$. latirostris resemble those of its ancestors and extend to the other crocodilians, since they exhibit inter- and intraspecific behavioral similarities.
\end{abstract}

Keywords: forelimb, broad snouted caiman, bones

\section{Introduction}

The development of the skeleton is better understood through new discoveries, based on reference tissue that undergoes a dynamic process of formation and resorption. Bones can be formed both from cartilage models and from mesenchymal condensation. Once formed, the skeletal frame is responsible for supporting the body, protecting the internal organs, and aiding movements, as well as for hematopoiesis, mineral homeostasis and the storage of triglycerides (Ortega et al., 2004).

It is well known that the morphology of reptiles differs both macro- and microscopically from that of other species. Therefore, comparative knowledge about the anatomy of these animals can clarify interspecific differences. It should be noted that the reconstruction of dinosaur skeletons has allowed for functional and behavioral inferences about these animal (Schumacher, 1996).

Caiman latirostris, or broad-snouted caiman, is a South American crocodilian (Brazil, Bolivia, Argentina, Uruguay, Paraguay) (Vilela, 2008) of medium size, with a characteristically broad snout, which may reach a length of up to three meters, although specimens longer than two meters are not commonly found (Piña et al., 2003; Vilela, 2008; Simoncini et al., 2009). Since 2003, the International Union for Conservation of Nature and Natural Resources has considered this species at low risk of extinction (Britton, 2009; IUCN, 2008; Queiroz \& Aoyama, 2009).

Scientific and teaching activities are supplemented with skeletons, which provide reliable information about the specific adaptations of vertebrates, such as support, posture and locomotor system (Hildebrand \& Goslow, 2006), and allow for anatomical and phylogenetic analyses that help expand our knowledge about biodiversity (Auricchio \& Salomão, 2002).

By describing the skeletal anatomy of the pectoral girdle, stylopodium and zeugopodium of Caiman latirostris, it was inted to contribute to the body of morphological information about this species, whit in turn, is acres, talk in a direct an d objective on the part of the skeletal anatomy of a brazilian crocodilian, so that from it, consider the 
related species, given the of behavior of these animals.

\section{Material and Method}

This study involved a young ( 5 to 8 years old) adult male specimen of $C$. latirostris, $1.50 \mathrm{~m}$ in length, which was fixed in $10 \%$ formol, belonging to the collection of the Wildlife Teaching \& Research Laboratory of the Federal University of Uberlândia.

The specimen's skin, viscera and pectoral girdle, stylopodium and zeugopodium bone muscles were removed, and the bones were identified, recorded in photographs taken with a digital camera, and then anatomically described.

\section{Results}

\subsection{Pectoral Girdle - Scapula and Coracoid Process}

The pectoral girdle comprises the scapula and coracoid process and articulates with the bones of the forelimb (Table 1).

Table 1. Description of the pectoral girdle, stylopodium and zeugopodium bones of Caiman latirostris

\begin{tabular}{|c|c|c|c|}
\hline Bone & Type & Location & Characteristics \\
\hline Scapula & Flat & Pectoral girdle (dorsal view) & Articulates with the coracoid and humerus \\
\hline Coracoid process & Flat & Pectoral girdle (ventral view) & Articulates with the scapula and humerus \\
\hline Humerus & Long & Zeugopodium & $\begin{array}{l}\text { Articulates proximally with the glenoid } \\
\text { cavity and distally with the radius and ulna }\end{array}$ \\
\hline Radius & Long & Cranial stylopodium & $\begin{array}{l}\text { Articulates proximally with the humerus } \\
\text { and distally with the carpus (cranial) }\end{array}$ \\
\hline Ulna & Long & Caudal stylopodium & $\begin{array}{l}\text { Articulates proximally with the humerus } \\
\text { and distally with the carpus (caudal) }\end{array}$ \\
\hline
\end{tabular}

\subsection{Scapula}

Extending in the cranial dorsal direction, the scapula has a narrow articular surface that hinges onto the coracoid process, projecting part of the glenoid cavity through an expanded groove, characteristically sellar, which in turn articulates with the elongated humeral head, congruent to the corresponding articular surface. It has cranial and caudal borders, the former proximal, deep and short and the latter less accentuated and horizontal. The points of origin of the deltoid and teres major scapular muscles, as well as their areas of insertion, are visible in the dorsal, cranial and caudal distal sides of the scapula, respectively. Proximal to the glenoid cavity is a rough area to which are attached part of the ventral portion of the humeral scapular muscle and, caudally, on a convex surface, the origin of the clavicular deltoid (Figure 1).

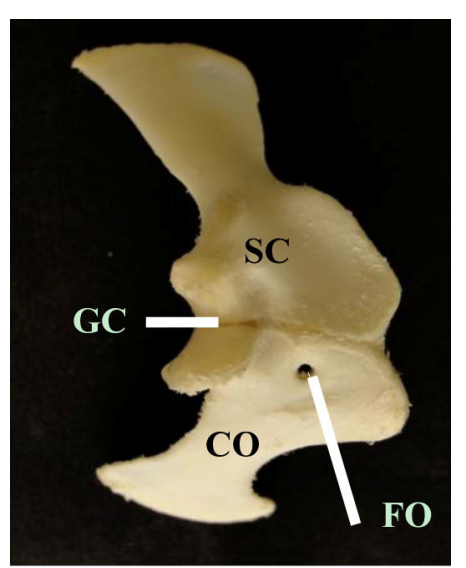

Figure 1. Photograph of the pectoral girdle of the right antimere of Caiman latirostris, dorsal view. CO, coracoid; GC, glenoid cavity; FO, foramen of the coracoid; SC, scapula 


\subsection{Coracoid Process}

Extending in the cranial ventral direction, the coracoid process appears large, with cranial and caudal sides, the former more accentuated and following an intermediate location and the latter shallower and horizontal. Its diameter is similar to that of the scapula, marked by the presence of a conspicuous foramen proximal to the scapulocoracoid joint, as well as a vertical line along which is visible the attachment of origin of the brachial biceps muscle. The contribution of the coracoid process to the formation of the glenoid cavity is as described for the scapula. Proximal to the medial border is a considerably large rough area from which the long supracoracoid muscle originates (Figure 1).

\subsection{Stylopodium - Humerus}

The humerus has the typical characteristics of a long bone. This osseous structure consists of a curved diaphysis and two epiphyses. The diaphysis is laterally convex, with a medial concavity. The two articular extremities correspond, respectively, to a proximal and a distal epiphysis (Figure 2).

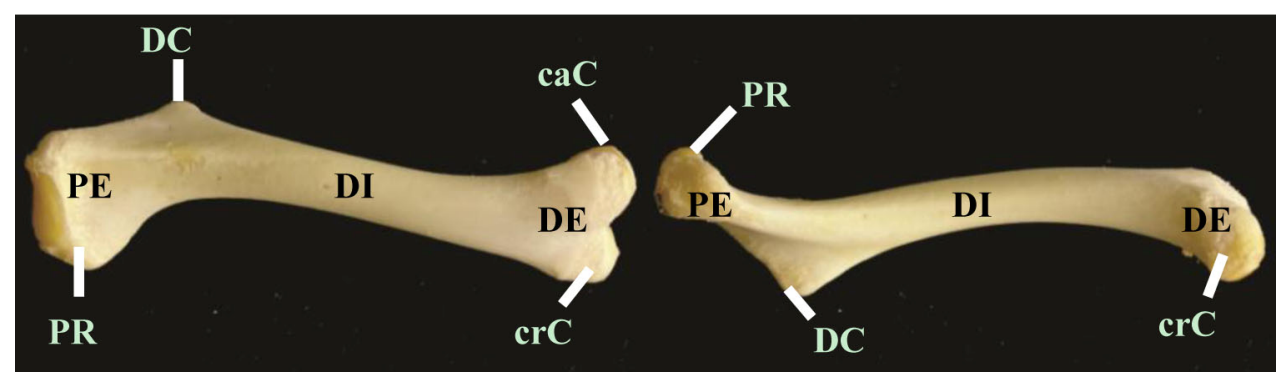

Figure 2. Photograph of the Stylopodium - Humerus of Caiman latirostris, A - Lateral view do right antimere, and B - Medial view of the right antimere. PR, protuberance; DC, deltoid crest, PE, proximal epiphysis; DI, diaphysis; DE, distal epiphysis; caC, caudal condyle; $\mathrm{crC}$, cranial condyle

An elongated surface in the proximal epiphysis articulates with the glenoid cavity, forming a continuous medial protuberance with the articular side, indicating the insertion point of the subscapularis muscle. Proximal to the articular surface of the humerus with the glenoid cavity is a prominent projection called the deltoid crest, into which the clavicular deltoid and scapular deltoid muscles are inserted cranially. A lateral view reveals an elongated elevation starting proximal to the humeral head and extending to the cranial level of the deltoid crest, in an intermediate location, serving as the point of insertion of the origin of the cranial triceps muscle. In addition, the insertion of the ventral coracobrachial muscle is visible medially in a triangular area proximal to the glenohumeral joint and caudally to the crest deltoid.

The distal epiphysis shows two rounded asymmetric protuberances known as condyles, separated by a small depression, followed by their respective cranial and caudal epicondyles articulating with the radius (cranial) and the ulna (caudal) (Figure 2).

\subsection{Zeugopodium - Radius and Ulna}

\subsubsection{Radius}

The radius has the typical characteristics of a long bone, and is clearly more slender than the ulna. It has a cylindrical diaphysis and proximal and distal epiphyses. The proximal articular surface articulates with the cranial condyle of the humerus and caudally with the ulna. The distal articular surface articulates with the carpal radial bone, and caudally with the ulna. The diameter of the proximal epiphysis is not as large as that of the distal epiphysis. The former shows a discrete proximal tuberosity highlighted caudally, which serves as the insertion point for the humeroradial and biceps muscles. Along the diaphysis, in the longitudinal caudal direction, is a slightly prominent border, which fixes the insertion of the pronator teres muscle (Figure 3). 


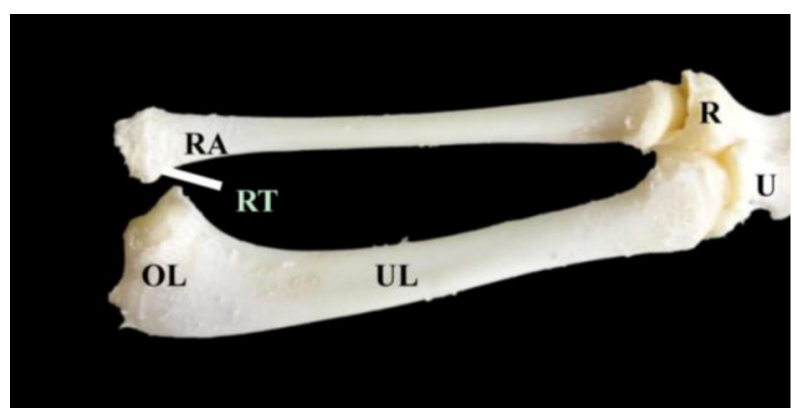

Figure 3. Photograph of the zeugopodium of Caiman latirostris - Lateral view of the right antimere. RA, radius; UL, ulna; PI, pisiform; R, radial; U, ulnar, OL, olecranon; RT, radial tuberosity

\subsubsection{Ulna}

The ulna has the typical characteristics of a long bone, notably more robust than the radius, whose diameter diminishes distally. It has a wide and curved diaphysis with a lateral convexity, presenting an intermediate groove for the attachment of the extensor carpi radialis brevis muscle. The ulna has proximal and distal epiphyses, the proximal attached to the caudal humeral condyle and unmistakably thicker, as well as a broad rounded olecranial projection articulated cranially with the radius. The distal articular surface articulates with the carpus and cranially with the radius (Figure 3 ).

\section{Discussion}

The forelimbs of $C$. latirostris are shorter than its hindlimbs, according to Oven's description (1855) of crocodilians, indicating greater potential for aquatic movements in detriment to terrestrial motion, resembling those of Desmatosuchus haplocerus (Case, 1920) (Aetossauria: Stagonolepididae (Small, 1985).

In Herrerasaurus ischigualastensis (Saurischia: Herrerasauridae) (Reig, 1963), as described by Sereno (1993), the narrow and extended scapula with the presence of an acromion and the small coracoid process show no similarity with C. latirostris. However, the two species show similarities with respect to the sellar glenoid cavity and the elongated convex humeral head, although they differ in the medial protuberance of the proximal epiphysis, which in $H$. ischigualastensis is not reported to be continuous with the surface articular, characterizing the majority of dinosaurs (Raath, 1977).

The scapula and coracoid process of crocodilians have been described as partially separate elements (Reese, 1915), as was observed in this study, in view of the articular fusion up to the ventral medial third in C. latirostris, which is found in the same arrangement in Caiman crocodilus, as demonstrated by Brochu (1995). It has been reported that these bone structures fused during ontogeny in pterosaurs (Wellnhofer, 1975; Bennet, 1993), in some dinosaurs (Galton, 1982; Rowe, 1989; Bonaparte et al., 1990; Raath, 1990; Rowe \& Gauthier, 1990; McIntosh, 1992; Sereno, 1994), and in Alligator mississippiensis (Brochu, 1995).

The asymmetry of the humeral condyles in this study is clearly evident from the greater caudal expansion, due to the increased articular congruence with the ulna, which in turn projects a large and broad olécrano, like in Cryolophosaurus ellioti (Dinosauria: Theropoda), as demonstrated by Smith et al. (2007). The thickness along the entire shaft of the radius differs less than in that of the ulna, and its proximal epiphysis is more prominent, with caudally inverted relationships, similar to that found in Eosuchus lerichei (Dollo, 1907) (Aligatoridae: Gavialoidea) by Delfino et al. (2005).

This compilation confirmed that the ulna and radius of $H$. ischigualastensis, according to Sereno (1994), and in crocodilians according to Reese (1915), present borders (cranial and caudal) along their respective diaphyses, indicative of the location of attachment of the interosseous membrane, which is more pronounced in the ulna, and also a well defined radial tuberosity.

\section{Conclusions}

Our findings led to the conclusion that the characteristics of the skeletal anatomy of the pectoral girdle, stylopodium and zeugopodium of $C$. latirostris resemble those of its ancestors and to the other crocodilians, since they exhibit inter- and intraspecific behavioral similarities. 


\section{References}

Auricchio, P., \& Salomão, M. D. G. (2002). Técnicas de coleta e preparação de vertebrados para fins científicos e didáticos. São Paulo: Aruja Instituto Pau Brasil de História Natural. p. 350.

Bennett, S. C. (1993). The ontogeny of Pteranodon and other pterosaurs. Paleobiology, 19, 92-106.

Bonaparte, J. F., Novas, F. E., \& Coria, R. A. (1990). Carnotaurus sastrei Bonaparte, the horned, lightly- built carnosaur from the Middle Cretaceous of Pa- tagonia. Contributions in Science of the Los An-geles County Museum, 416, 1-42.

Britton, A. (2009). Caiman latirostris (Daudin, 1801). Crocodilian Biology Data Base. Disponível em< http://www.flmnh.ufl.edu/cnhc/cbd-gb3.htm > acesso em: 03/09/09

Brochu, C. A. (1995). Heterochrony in the cocodylian sapulocoracoid. Journal of Herpetology, 29(3), 464-468. http://dx.doi.org/10.2307/1565002

Delfino, M., Piras, P., \& Smith, T. (2005). Anatomy and phylogeny of the gavialoid crocodylian Eosuchus lerichei from the Paleocene of Europe. Acta Palaeontologica Polonica, 50(3), 565-580.

Dodson, P., \& Osmlska, H. (eds.). The Dinosauria. University of California Press: Berkeley, p. 870.

Galton, P. M. (1982). Juveniles of the stegosaurian dinosaur Stegosaurus from the Upper Jurassic of North America. Journal of Vertebrate Paleontology, 2, 47-62. http://dx.doi.org/10.1080/02724634.1982.10011917

Hildebrand, M., \& Goslow, J. R. (2006). Análise da estrutura dos vertebrados. 2. ed. São Paulo: Atheneu, p. 700.

IUCN-SSC, Crocodile Specialist Group. (2008). International Union for Conservation of Nature and Natural Resources. Locomotion. Crocodilian Biology. Disponível em<www.iucnredlist.org $>$ acesso em: 03/09/09

Mcintosh, J. S. (1992). Sauropoda the Dinosauria. In: Weishampel, D. B.; DODSON, P., Osmlska, H. (eds) California Press: Univ., Berke- ley., p. 345-401.

Ortega, N., Danielle, J., Behonick, D. J. B., \& Werb, Z. (2004). Matrix remodeling during endochondral ossification. Science Direct, 14(2), 86-93.

Piña, C. L., Larriera, A., \& Cabrera, M. R. (2003). Efect of incubation temperature of incubation period, sex ratio, hatching success, and survivorship in Caiman latirostris (Crocodilia - aligatoridae). Journal of herpetology, 37(1), 199-222.

Queiroz, P. P. R., \& Aoyama, P. M. (2009). List of Studies on the Alligator-de-snouted Caiman (Caiman latirostris - DAUDIN, 1802). Disponível em<http://www.flmnh.ufl.edu/cnhc/csp_clat.htm $>$ acesso em: 03/09/09

Raath, M. A. (1977). The anatomy of the Triassic theropod Syntarsus rhodesiensis (Saurischia: Podokesauridae) and a consideration of its biology. Ph.D. Dissertation, Rhodes University, South Africa.

Raath, M. A. (1990). Morphological variation in small theropods and its meaning in systematics: Evi-dence from Syntarsus rhodesiensis. p. 91-106. In: CARPENTER, K.; CURIE, P. J. (eds.). Dinosaur Systematics: perspectives and approaches. New York: Cambridge Univ. Press, p. 318. http://dx.doi.org/10.1017/CBO9780511608377.010

Reese, A. M. (1915). The Alligator and its Allies. New York: Putnam's Sons, p.358.

Rowe, T. (1989). A new species of the theropod dinosaur Syntarsus from the early jurassic kayenta formation of Arizona. Journal Veterinary Paleontology, 9, 125-136. http://dx.doi.org/10.1080/02724634.1989.10011748

Rowe, T. A., Gauthier, J., \& Ceratosauria. (1990). In: Weishampel, D. B. p. 151-168.

Schumacher, J., Reptiles, \& Amphibians. (1996). Williams, Willkins In: Grim, K. A., Tranquilli, W. J., Thurmon, J. C. Lumb \& Jones Veterinary Anesthesia. 3. ed. Pennsylvania: Ilustrated, p. 928.

Sereno, P. C. (1994). The Pectoral girdle and forelimb of the basal theropod Herrerasaurus ichigualastensis. Journal of Vertebrate Paleontology, 13(4), 425-450. http://dx.doi.org/10.1080/02724634.1994.10011524

Simoncini, M. S., Piña, C. I., \& Siroski, P. A. (2009). A clutch size of Caiman latirostris (crocodilia aligatoridae), varies on a latitudinal gradient. North-westenrs Journal of Zoology, 5(1), 191-196.

Small, B. J. (1985). The triassic thecodontian reptile desmatosuchus osteology and relationships. Texas: Marter of artes, p. 83.

Smith, N. D., Makovicky, P. J., Hammer, H., \& Currie, P. J. (2007). Osteology of Cryolophosaurus ellioti 
(Dinosauria: Theropoda) from the Early Jurassic of Antarctica and implications for early theropod evolution. Zoological Journal of the Linnean Society, http://dx.doi.org/10.1111/j.1096-3642.2007.00325.x

Vilela, P. M. S. (2008). Caracterização genética de crocodilianos e desenvolvimento de marcadores macrossatélites para Paleosuchus trigonatus. 2008. 131 f. Tese (Doutorado em ecologia aplicada) Escola superior de agricultura Luiz de Queiroz, Universidade de São Paulo, Piracicaba.

Wellnhofer, P. (1975). Die rhamphorhynchoidea (Pterosauria) der oberjura-plattenkalke sii- deutschlands. Palaeontographica, 148, 1-33. 